\title{
Hubungan antara Kepuasan Kerja dan Komitmen Organisasi Terhadap Organizational Citizenship Behavior pada Karyawan
}

\author{
Rani Tunbaity Gultom, Noor Erdianza, dan Rion Nofrianda \\ Pascasarjana Magister Profesi Psikologi Universitas Ahmad Dahlan \\ ranigultom94@gmail.com, echaerdianza@gmail.com, rionnofrianda@gmail.com
}

\begin{abstract}
The purpose of this study was to examine the relationship between work satisfaction, organization commitment to organizational citizenship behavior employees. A measuring tool used in this study is the scale of organizational citizenship behavior, work satisfaction, and organization commitment. The sampling technique used was random sampling. The sample population of this study is the employee of company X in Yogyakarta who has a position at low manager. There are 43 employees respondent. This study uses data processing test using SPSS version 21.0 for windows. We use regressions test analysis and the result are a) Ha received, $r=0,616$ with a value of $p=0.000$, $p<0.05$ means that job satisfaction and $O C B$ are positively correlated and highly significant. b) Ha received, $r=0,322$ with a value of $p=0.018, p<0.05$ means that organizational commitment and OCB correlated positively and significantly. c) Ha received, $r=0,448$ with a value of $p=0.001, p<0.05$ means that job satisfaction and organizational commitment positively and significantly correlated. $d$ ) Ha received, $r=0,379$ with a value of $p=$ $0.000, p<0.05$ means that job satisfaction and organizational commitment and OCB are positively correlated and highly significant.
\end{abstract}

Keywords: Job Satiisfaction, Organization Commitment, OCB

\begin{abstract}
Abstrak
Tujuan dari penelitian ini adalah untuk menguji hubungan antara kepuasan kerja, komitmen organisasi dengan perilaku warga organisasi organisasi. Alat ukur yang digunakan dalam penelitian ini adalah skala OCB, kepuasan kerja, dan komitmen organisasi. Teknik pengambilan sampel yang digunakan adalah random sampling. Populasi sampel penelitian ini adalah karyawan perusahaan X di Yogyakarta yang memiliki posisi di manajer rendah. Ada 43 karyawan responden. Penelitian ini menggunakan analisa data menggunakan SPSS versi 21.0 for windows. Peneliti menggunakan analisis uji regresi dan hasilnya adalah a) Ha diterima, $r=0,616$ dengan nilai $p=0,000, p$ $<0,05$ berarti bahwa kepuasan kerja dan OCB berkorelasi positif dan sangat signifikan. b) Ha diterima, $r=0,322$ dengan nilai $p=0,018, p<0,05$ berarti bahwa komitmen organisasi dan OCB berkorelasi positif dan signifikan. $c$ ) Ha diterima, $r=0,448$ dengan nilai $\mathrm{p}=0,001, \mathrm{p}<0,05$ berarti kepuasan kerja dan komitmen organisasi berkorelasi positif dan signifikan. d) Ha diterima, $r=0,379$ dengan nilai $p=0,000, p<0,05$ berarti bahwa kepuasan kerja dan komitmen organisasi dan OCB berkorelasi positif dan sangat signifikan.
\end{abstract}

Kata Kunci: Kepuasan kerja, Komitmen organisasi, OCB

\section{Pendahuluan}

Perusahaan tentu saja memiliki masalah yang kompleks dalam menjalankan organisasinya, masalah muncul dari individu dengan individu lainnya, individu dengan kelompok bahkan individu dengan organisasi. Organisasi harus memberi perhatian ekstra tehadap karyawannya. Mengingat pentingnya Sumber Daya Manusia (SDM) dalam suatu organisasi, karena keefektifan dan keberhasilan suatu organisasi sangat tergantung pada kualitas dan kinerja sumber daya manusia yang ada pada organisasi tersebut. Kinerja sumber daya manusia (karyawan) yang tinggi akan mendorong munculnya organizational citizenship behavior (OCB), yaitu perilaku melebihi apa yang telah distandarkan perusahaan (Krietner dan Kinicki, 2004).

Organizational citizenship behavior menjadi hal yang positif bagi perkembangan sebuah organisasi, begitupun di Perusahaan X yang bergerak dibidang kuliner, merupakan restoran yang selalu ramai didatangi konsumen setiap harinya. Hal ini diungkapkan oleh salah seorang karyawan berinisal D, wawancara dilakukan pada hari rabu, tanggal 21 September 2016. Wawancara dilakukan pada waktu istirahat. Tingginya angka kedatangan pengunjung setiap harinya membawa konsekuensi pada

Diterima Redaksi : 23-12-2019 | Selesai Revisi : 20-01-2020 | Diterbitkan Online : 21-01-2020 
pemeliharaan maupun peningkatan kinerja berupa baiknya kualitas pelayanan karyawan kepada customers restoran. Munculnya organizational citizenship behavior dapat menjadi gambaran adanya kinerja yang tinggi dalam organisasi.

Organizational citizenship behavior dapat berupa perilaku kerja ekstra dan perilaku prososial anggota dalam suatu organisasi. Hal ini didukung oleh pernyataan Borman dan Motowidlo (1993) yang mengatakan bahwa OCB dapat meningkatkan kinerja organisasi karena OCB merupakan "pelumas" dalam mesin sosial dalam organisasi. OCB adalah salah satu kunci sukses dalam meningkatkan performa organisasi. Menurut Williams dan Anderson (1991) Organizational citizenship behavior (OCB) meningkatkan efisiensi dan efektifitas organisasi dengan memberikan kontribusi terhadap transformasi sumber daya, inovasi dan daya adaptasi, karena itulah penting bagi anggota orgnisasi untuk memiliki OCB.

Organizational citizenship behavior dapat muncul dari berbagai faktor dalam sebuah organisasi, faktor tersebut diantaranya karena adanya kepuasan kerja dari karyawan dan komitmen organisasi yang tinggi (Robbin dan Judge, 2008). Khan (2006) juga mengemukakan bahwa kepuasan kerja dan komitmen organisasi menjadi hal yang penting dari OCB. Ketika karyawan merasakan kepuasan terhadap pekerjaan yang dilakukannya, maka karyawan tersebut akan bekerja secara maksimal dalam menyelesaikan pekerjaan, bahkan melakukan beberapa hal yang mungkin diluar tugasnya.

George (2003) mengemukakan bahwa kepuasan kerja sangat berperan terhadap OCB karena karyawan akan memberikan sesuatu kembali untuk perusahaan yang telah memperlakukan karyawan dengan baik. Al Ahmadi (2009) mengemukakan bahwa kepuasan kerja mempengaruhi kinerja seseorang. Kepuasan kerja mencerminkan perasaan seseorang terhadap pekerjaannya yang dapat terlihat dari sikap karyawan terhadap pekerjaan dan segala sesuatu di lingkungan pekerjaannya. Semua jenis perusahaan sebenarnya membutuhkan suatu sistem kerja yang secara serius memperhatikan hal kepuasan kerja para karyawannya. Menurut Davis \& Newstrom (1985) kepuasan kerja yang tinggi diinginkan oleh para manajer karena dapat dikaitkan dengan hasil positif yang mereka harapkan. Kepuasan kerja yang tinggi merupakan tanda bahwa organisasi yang dikelola dengan baik pada dasarnya merupakan hasil manajemen perilaku yang efektif. Selanjutnya, ketika seseorang mempunyai komitmen yang tinggi terhadap organisasinya, maka orang tersebut akan melakukan apapun untuk memajukan perusahaannya karena keyakinannya terhadap organisasinya (Luthans, 2006).

Menurut Steers (1985) mendefinisikan komitmen organisasi sebagai rasa identifikasi (kepercayaan terhadap nilai-nilai organisasi), keterlibatan (kesediaan untuk berusaha sebaik mungkin demi kepentingan organisasi) dan loyalitas (keinginan untuk tetap menjadi anggota organisasi yang bersangkutan) yang dinyatakan oleh seorang karyawan terhadap perusahaannya. Berdasarkan hasil penelitian oleh Sianipar dan Haryanti (2014) mengemukakan bahwa komitmen organisasi merupakan sebuah perasaan dan sikap karyawan terhadap organisasinya, sepenuh hati mengikuti aturan perusahaan, dan memberikan kontribusi yang terbaik untuk tujuan serta kemajuan perusahaan. Komitmen yang tinggi menjadikan seseorang lebih mementingkan organisasi dari pada kepentingan pribadi dan berusaha menjadikan organisasi menjadi lebih baik. Komitmen organsiasi yang rendah akan membuat seseorang untuk berbuat demi kepentingan pribadinya (Greenberg dan Baron, 2003).

Ketika seseorang mendapatkan kepuasan kerja dan mempunyai komitmen yang tinggi terhadap organisasi, karyawan akan memberikan pelayanan yang baik dan begitu juga sebaliknya, ketika karyawan saja tidak mengalami kepuasan maka pelayanan yang diberikan kepada konsumen, dalam hal ini pelanggan dapat tidak terpuaskan. Kepuasan kerja diartikan sebagai tanggapan emosional seseorang terhadap aspek-aspek di dalam atau pada keseluruhan pekerjaannya (Nawawi, 1998). Keadaan emosional atau sikap seseorang tersebut akan diperlihatkan dalam bentuk tanggungjawab, perhatian, serta perkembangan kinerjanya.

Berdasarkan latar belakang di atas, penulis tertarik untuk meneliti hubungan antara kepuasan kerja dan komitmen organisasi terhadap organization citizenship behavior pada karyawan di Perusahaan X di Yogyakarta.

\section{Metode Penelitian}

Penelitian ini menggunakan pendekatan kuantitatif dengan analisis statistik yang menitikberatkan pengujian hipotesis. Jenis penelitian yang digunakan yaitu penelitian korelasional. Teknik pengambilan sampel menggunakan random sampling, sehingga jumlah sampel populasi dalam penelitian ini 
berjumlah 43 orang karyawan di Perusahaan X Yogyakarta. Variabel Y dalam penelitian ini adalah Organizational citizenship behavior. Skala yang digunakan berdasarkan teori OCB dari Podsakoff dan MacKenzie (1994) dan telah diadopsi oleh Wirawan (2013), meliputi: (a) alturism, (b) conscientiousness, (c) civic virtue, (d) sportsmanship, dan (e) courtesy,

Skala penelitian kepuasan kerja menggunakan Anggraini (2016) berdasarkan pengukuran kepuasan kerja menurut Luthans (2006) meliputi: (a) pembayaran gaji atau upah, (b) pekerjaan itu sendiri, (c) rekan kerja, (d) kesempatan promosi, (e) pengawasan.

Skala penelitian komitmen organisasi menggunakan Allen dan Mayer yang direvisi oleh Jaros (2007) dan telah diadopsi oleh Aulia (2015) meliputi: (a) komitmen afektif, (b) komitmen normatif, dan (c) komitmen continuance.

Pengujian hipotesis menggunakan teknik korelasi product moment. Teknik statistik dalam penelitian ini menggunakan program SPSS 19 for windows.

\section{Hasil dan Pembahasan}

\section{Deskripsi Data}

Data yang diperoleh melalui 43 responden, pernyataan kepuasan kerja 21 butir dengan rentang skor terendah 43 dan yang tertinggi 79 dengan nilai mean 58.6; Pernyataan komitmen organisasi sebanyak 24 dengan rentang skor terendah 42.00 dan yang tertinggi 79.00 dengan nilai mean 62.2; pernyataan OCB sebanyak 16 butir dengan rentang skor terendah 41 dan yang tertinggi 59 dengan nilai mean 47.8 . Hasil Uji Normalitas dan Linieritas

Berdasarkan hasil analisis uji normalitas One-Sample Kolmogrov-Swirnov Test diperoleh nilai normalitas masing-masing variabel yaitu diketahui bahwa skala kepuasan kerja diperoleh nilai signifikansi sebesar 0.564 ( $p>0.05$ ), skala komitmen organisasi diperoleh nilai signifikansi sebesar 0.380 ( $>0.05$ ) dan skala OCB diperoleh nilai signifikansi sebesar 0.396 ( $p>0.05$ ), sehingga sebaran data skala kepuasan kerja, komitmen organisasi dan OCB dianggap normal.

Hasil uji linieritas pada variabel kepuasan kerja dengan OCB diketahui bahwa $\mathrm{F}=52.344$ dengan taraf signifikansi 0.000. Pada variabel komitmen organisasi dengan OCB diketahui bahwa $\mathrm{F}=5.369$ dengan taraf signifikansi 0.030. Dari hasil pengujian ini signifikansi memenuhi syarat $\mathrm{p}<0.05$.

\section{Hasil Uji Hipotesis}

Hasil pengujian hipotesis mengunakan analisis regresi berganda, diperoleh hasil bahwa;

Hipotesis pertama, $r=0,616$ dengan nilai $p=0.000$, sehingga $p<0.05$ artinya sangat signifikan. Hal ini menunjukkan secara keseluruhan ada hubungan positif yang sangat signifikan antara kepuasan kerja dengan OCB, jadi hipotesis pertama diterima.

Hipotesis kedua, $r=0,322$ dengan nilai $\mathrm{p}=0.018$, sehingga $\mathrm{p}<0.05$ artinya signifikan. Hal ini menunjukkan secara keseluruhan ada hubungan positif yang signifikan antara komitmen organisasi dengan OCB, jadi hipotesis kedua diterima.

Hipotesis ke tiga, $r=0,448$ dengan nilai $\mathrm{p}=0.001$, sehingga $\mathrm{p}<0.05$ artinya signifikan. Hal ini menunjukkan secara keseluruhan ada hubungan positif yang signifikan antara kepuasan kerja dengan komitmen organisasi, jadi hipotesis ketiga diterima.

Hipotesis ke empat, $R=0,379$ dengan nilai $p=0.000$, sehingga $p<0.05$ artinya sangat signifikan. Hal ini menunjukkan secara keseluruhan ada hubungan positif yang sangat signifikan antara kepuasan kerja dan komitmen organisasi dengan OCB, jadi hipotesis ke empat diterima.

Hubungan positif yang sangat signifikan antara kepuasan kerja dengan OCB, yang berarti bahwa hipotesis yang diajukan diterima. Hal ini berarti bahwa semakin tinggi kepuasan kerja yang dimiliki karyawan maka akan meningkatkan OCB nya. Hal ini sesuai dengan pendapat Robbins (2008) yang meyatakan bahwa kepuasan kerja mendorong munculnya OCB karyawan karena karyawan yang puas memiliki kemunngkinan yang lebih besar untuk berbicara positif tentang organisasi, membantu individu lain dan melakukan kinerja yang melampaui perkiraan normal. Karyawan yang puas lebih patuh pada tugas karena mengulang pengalaman positif yang pernah dirasakan.

Hipotesis kedua menunjukkan ada hubungan positif yang signifikan antara komitmen organisasi dengan OCB. Hal ini menunjukkan bahwa semakin tinggi komitmen organisasi maka akan semakin tinggi pula OCB karyawan. Hal ini sesuai dengan pendapat yang dikemukakan oleh Organ (2006), OCB dipengaruhi oleh tiga faktor, salah satunya adalah faktor sikap kerja, yaitu emosi dan kognisi yang 
berdasarkan persepsi individu terhadap lingkungan kerja, meliputi: komitmen organisasi, persepsi kepemimpinan dan dukungan organisasi, person organization fit, kepuasan kerja, psychological contract, persepsi keadilan dan keadilan organisasi.

Hipotesis ketiga menunjukkan ada hubungan positif yang signifikan antara kepuasan kerja dengan komitmen organisasi. Hal ini menunjukkan bahwa semakin tinggi kepuasan kerja maka akan semakin tinggi komitmen organisasi karyawan. Hal ini memperkuat teori yang disampaikan oleh Luthans (2006) bahwa jika variabel yang positif terhadap kepuasan kerja yaitu tipe pekerjaan itu sendiri, gaji dan bayaran, kesempatan promosi, atasan dan rekan kerja dapat terpenuhi, maka komitmen terhadap organisasi akan timbul dengan baik. Sehingga kepuasan kerja berkolerasi positif dengan komitmen organisasi.

Hipotesis keempat dalam penelitian ini menunjukkan adanya hubugan positif yang sangat signifikan antara kepuasan kerja dan komitmen organisasi terhadap OCB. Semakin tinggi kepuasan kerja dan komitmen organisasi maka akan semakin tinggi pula OCB karyawan. Hal ini didukung oleh pernyataan Khan (2006) yang mengemukakan bahwa kepuasan kerja dan komitmen organisasi menjadi hal yang penting dari $\mathrm{OCB}$

\section{Kesimpulan}

Dari penelitian ini dapat diketahui mengenai hubungan antara kepuasan kerja dan komitmen organisasi terhadap organizational citizenship behavior pada karyawan. Berdasarkan analisis yang telah dilakukan diperoleh hasil bahwa pertama, terdapat hubungan positif yang sangat signifikan antara kepuasan kerja dengan OCB. Kedua, menunjukkan ada hubungan positif yang signifikan antara komitmen organisasi dengan OCB. Hal ini menunjukkan bahwa semakin tinggi komitmen organisasi maka akan semakin tinggi pula OCB karyawan. Ketiga, menunjukkan ada hubungan positif yang signifikan antara kepuasan kerja dengan komitmen organisasi. Hal ini menunjukkan bahwa semakin tinggi kepuasan kerja maka akan semakin tinggi komitmen organisasi karyawan. menunjukkan adanya hubugan positif yang sangat signifikan antara kepuasan kerja dan komitmen organisasi terhadap OCB

Peneliti selanjutnya, disarankan untuk melakukan penelitian pada sampel yang lebih besar dan juga beragam dari sisi usia, pendidikan, dan gender. Diharapkan penelitian berikutnya menggunakan teoriteori baru dan mempertimbangkan variabel-variabel lain serta dapat melakukan penelitian yang lebih mendalam dengan memperluas dan mengembangkan ruang lingkupnya.

\section{Daftar Rujukan}

Al-Ahmadi, H. (2009). Factors affecting performance of hospital nurses in Riyarh Saudi Arabia. International Journal of Health Care, 22(1), 40-54. doi:10.1108/09526860910927943.

Aulia. (2015). Komitmen organisasi ditinjau dari kecerdasan emosi dan keterikatan kerja. Fundamental. Yogyakarta: Universitas Ahmad Dahlan.

Anggraini, R. (2016). Pengaruh kepuasan kerja dan persepsi dukungan organisasi terhadap kebahagian pada karyawan PT. Pos Indonesia Pekanbaru. Tesis. Medan: Universitas Sumatra Utara.

Borman, W. C., \& Motowidlo, S. J. (1993). Expanding the criterion domain to include elements of extrarole performance, dalam Schmitt, N. \& Borman, W. C. (editors). Personel selection in organizations. San Francisco: Jossey-Bass.

Cetin, M. O. (2006) The relationship between job satisfication, occupational and organizational commitmen of academics. Journal Of American Academy Of Business, Cambridge, 8(1): 78-88.

Davis, K., \& Newstrom, J. W. (1985). Perilaku dalam organisasi. Jakarta: Erlangga.

George, R. T. (2003). Prinsip-prinsip management. Jakarta: PT. Bumi Aksara.

Greenberg, J. \& Baron, R. A. (2003). Behavior in organizations understanding and managing the human side of work. New Jersey: Prentice-Hall International.

Khan, A. (2006). Performance appraisal's relation with productivity and job satisfaction. Journal of Managerial Sciences, 1(2):114. Department of Management Science, Qurtuba University of Science $\&$ IT.

Kretner, R., \& Kinicki, A. (2005). Perilaku organisasi, buku 1 dan buku 2. Jakarta: Selemba 4 
Kumara, B. J. G. (2014). Hubungan antara komitmen organisasi dengan organizational citizenship behavior. Skripsi. Surakarta: Universitas Muhammadiyah Surakarta.

Luthans, F. (2006). Perilaku organisasi. Diterjemahkan oleh Vivin Andika, Yuwono dkk. edisi Pertama. Yogyakarta: Andi

Meyer, J., \& Allen, N. (1991). A three-component conceptualization of organizational commitment. Human Resource Management Review, 1(1), 61- 89.

Nawawi, H. (2003). Kepemimpinan Mengefektifkan Organisasi. Yogyakarta: Gadjah Mada University Press.

Organ, D. W., and Ryan, K. (1994), A Meta-analytic review of attitudinal and dispositional predictors of organizational citizenship behavior, Personnel Psychology, Vol. 48.

Organ, D. W. 2006. Organizational Citizenship Behavior: The Good Soldier Syndrome. Lexington, MA: Lexington Books.

Podsakoff, P. M., MacKenzie, S. B., Paine, J. B., \& Bachrach, D. G. (2000). Organizational citizenship behavior: A critical review of the theoretical and empirical literature and suggestions for future research. Journal of Management, 26: 513-563.

Riggio, R. E. (2009). Introduction to industrial/organizational psychology (5th ed.). New Jersey: Pearson Education International.

Robbins, S. P., \& Judge, T. A. (2008). Perilaku organisasi, edisi 12. Diterjemahkan oleh Diana Angelica, Ria Cahyani, dan Abdul Rosyid. Jakarta: Penerbit Salemba Empat.

Sianipar, A, R, B. \& Haryanti, K. (2014). Hubungan komitmen organisasi dan kepuasan kerja dengan intensi turnover pada karyawan bidang produksi CV.X. Psikodimensia, 13(1), 98-114.

Setiawati, A. N. (2015). Hubungan antara kepuasan kerja dengan organizational citizenship behavior pada karyawan PT. Bank Mandiri. Skripsi. Yogyakarta: UIN Sunan Kalijaga.

Steers, R. M. (1985). Efektivitas organisasi kaidah perilaku (alih bahasa Magdalena). Jakarta: Erlangga

Van, D. L., \& Grahama J.W. (2005). Organizational citizenship behavior; Construct redefinition measurement and validition, Academiy Management Journal, 37 (4) pp 765-802

Williams, L. J., \& Anderson, S. E. (1991). Job satisfaction and organizational commitment as predictors of organizational citizenship and in-role behaviors. Journal of Management, 17(3), 601-6

Wirawan, M. H. (2013). Pengaruh keterlibatan kerja dan organizational based self esteem terhadap organizational citizenship behavior. Skripsi. Jakarta: UIN Syarif Hidayatull 